\title{
Investigation of Anaerobic Digestion of Organic Solid Waste
}

\author{
${ }^{1}$ Mr.R.Balamurugan, ${ }^{2} \mathrm{Mr}$. M.Manikandan, ${ }^{3} \mathrm{Mr}$. B.Arulmurugan, ${ }^{4} \mathrm{Mr}$. K.Subash \\ ${ }^{1}$ Assistant professor, ${ }^{2,3,4}$ Student, MRK INSTITUTE OF TECHNOLOGY, Kattumannarkovil, \\ Tamil Nadu, India. 1balacivil1616@gmail.com, ${ }^{2}$ manimithran26111999@gmail.com, \\ ${ }^{3}$ nagarajheartly@gmail.com, ${ }^{4}$ Subashcivil1997@gmail.com
}

Abstract The technology of anaerobic digestion of organic solid wastes is, in many aspects, mature. Topics such as fundamentals (kinetics, modeling, etc...) Process aspects performance, two and single phase systems, wet technologies, digestion enhancement of several treatments. Digestion with other substrates and its relation to composting technology are examined in this review. Special attention is paid to the advantages of anaerobic digestion in limiting the emission of greenhouse gases. An overview of industrial achievements and future developments. Municipal solid waste management (MSWM) is one of the major environmental problems of Indian cities. Improper management of municipal solid waste (MSW) causes hazards to inhabitants. Various studies reveal that about $90 \%$ of MSW is disposed of unscientifically in open dumps and landfills, creating problems to public health and the environment. In the present study, an attempt has been made to provide a comprehensive review of the characteristics, generation, collection and transportation, disposal and treatment technologies of MSW practiced in India Special attention is paid to the advantages of anaerobic digestion in limiting the emission of greenhouse gases. On overview domestic and organic waste achievement and future development.

Keywords — Biogas, treatment, lechate, organic waste, anaerobic digestion process.

\section{INTRODUCTION}

Anaerobic digestion is worldwide used, particularly in Europe for the treatment of numerous types of biodegradable wastes. Biogas rectors are gaslight chambers in which organic solid waste are degraded and converted into biogas by microorganism in absence of via a process is called anaerobic digestion.

This is confirmed by the important number of treatment plants using this process on the industrial scale, during the past few years. In fact, anaerobic digestion of the organic fraction of the municipal solid wastes alone or combined with organic can contribute efficiently in solid waste reduction and biogas production.

This process can be used for the solid waste treatment under domestic waste of organic solid. Wastes with or without wastewater treatment plant due to the importance of anaerobic digestion as a treatment process, different dynamic models exist.

\section{BIO-GAS}

Biogas is the mixture of gases produced by the breakdown of organic matter in the absence of oxygen (anaerobically), primarily consisting of methane and carbon dioxide. Biogas can be produced from raw materials such as agricultural waste, manure, municipal waste, plant material, sewage, green waste or food waste

\section{WASTE TREATMENT}

Waste treatment refers to the activities required to ensure that waste has the least practicable impact on the environment.

\section{LEACHING WATER}

In agriculture, leaching is the loss of water-soluble plant nutrients from the soil, due to rain and irrigation. ... As water from rain, flooding, or other sources seeps into the ground, it can dissolve chemicals and carry them into the underground water supply.

\section{V.MANURE}

Manure is organic matter that is used as organic fertilizer in agriculture. Manure consists of animal feces; other sources include compost and green manure.

the release of pollutants, conserve resources, save energy and reduce the demand for waste treatment technology and landfill space. Therefore it is advisable that these methods be adopted and incorporated as part of the waste management plan.

\section{VI.ORGANIC WASTE}


Organic waste, or green waste, is organic material such as food, garden and lawn clippings. It can also include animal and plant based material and degradable carbon such as paper, cardboard and timber. Burying organic waste in landfill is a big problem and it's not just because of the resources we lose.

\section{VII.IN-ORGANIC WASTE}

Inorganic wastes (also known as non-biodegradable waste) are chemical substances of mineral origin. They include waste material such as sand, salt, Iron, Calcium, and other mineral materials that are only slightly affected by the action of organisms.

\section{SUGAR CANE WASTE}

Biogases are the dry pulpy fibrous residue that remains after sugarcane or sorghum stalks are crushed to extract their juice. It is used as a bio fuel for the production of heat, energy, and electricity, and in the manufacture of pulp and building materials.

\section{VEGETABLE WASTE}

Waste, comprised mainly of vegetable matter, which is capable of being decomposed by microorganisms.

\section{X.GOAT DUNGS}

The farmers shall examine the ways in which they can take advantage of their goats waste. They can use it as manure in their crops.

\section{SOLID PARTICLES}

A solid is a state of matter characterized by particles arranged such that their shape and volume are relatively stable. The constituents of a solid tend to be packed together much closer than the particles in a gas or liquid.

Human ways of life have placed pressure on the environment and have caused imbalance in the eco systems by the producing, consuming and wasting of natural resources. Most countries evidently have major effects on the environment due to SW generation with economic development since the natural resources are used, and waste and pollution are produced. Therefore, the concern towards the management of solid waste as an integral part for sustainable development has increased.

\section{OBJECTIVE \& AIMS}

* To digestion of organic solid waste and reduction of waste materials such as domestic waste, industries vegetable waste and other organic waste.

* The process is made of natural manure to use agricultural purpose and etc.. The digestion help of using materials are sugar cane and goat dung

* To evaluate the operation performance of anaerobic reactors treating the organic fraction of municipal solid waste.

* To determine the potential methane production of anaerobic degradation of bio waste and other types of waste namely food waste, press water and potato sludge.

* To examine the characteristics of different organic solid wastes which are potential substrates for anaerobic digestion.

* To examine the stability of the solid waste substrates if they are used as a sole substrate in anaerobic digestion.

* To determine the maximum loading rate of the anaerobic reactors treating bio waste from municipal solid waste if co digested with other types of wastes.

* Besides composting or direct animal feeding, anaerobic digestion of organic solid waste is considered promising treatment option for this particular waste fraction.

* Anaerobic digestion is a natural biological process that converts biomass into energy (biogas) in the absence of oxygen.

\section{XIII.ADVANTAGE}

i. To reduce organic solid waste

ii. Generation of methane gases.

iii. Less harmful effect.

iv. To form manure and to use agriculture purpose.

v. Good pathogen removal depending on temperature. Process stability to provide.

vi. It reduces odour below unprocessed waste odour levels. It is much less likely to cause environmental pollution than spreading untreated organic waste on land.

vii. The effect of the fertilizer is longer lasting than for untreated organic waste.

viii. Anaerobic digestion creates biogas, a renewable source of energy that can be used similar to natural gas.

ix. Food and other organic materials disposed of in landfills decompose to create methane, a greenhouse gas with a global warming potential 21 times higher than carbon dioxide.

\section{XIV.DISADVANTAGE}

i. Small and middle scale anaerobic technology for the treatment of solid waste in middle and low income countries.

ii. Sulphurous compounds can lead to odour.

iii. High sensitivity of bacteria to a large number of chemical compounds.

iv. When carried out at a commercial scale on farms and at wastewater treatment works it requires a high level of investment in large tanks and other process vessels.

v. If run inefficiently AD can cause an odor nuisance

vi. When carried out at a commercial scale on farms 
and at wastewater treatment work it requires a high level of investment in large tanks and other process vessels.

vii. Does not convert as large a proportion of the carbon in the biomass to biogas as can be achieved using gasification.

\section{XV.WHY FOOD WASTE}

Food waste is the second largest category of municipal solid waste (MSW) sent to landfills in the United States, accounting for approximately $18 \%$ of the waste stream. Over 30 million tons of food waste is sent to landfills each year. Of the less than $3 \%$ of food waste currently being diverted from landfills, most of it is being composted to produce a fertilizer.

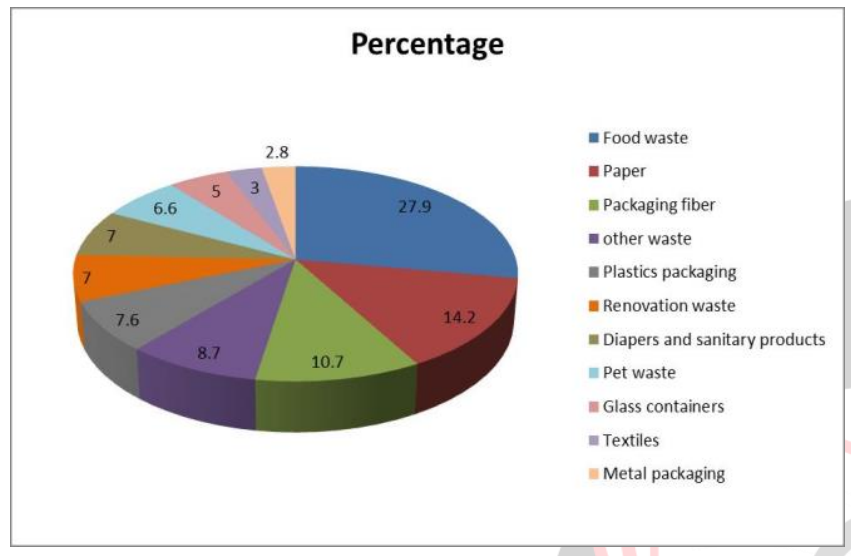

Fig: 1 WASTE PRODUCTION

\section{Waste Diversion Goals}

Many states and local governments currently have mandated diversion goals. Aggressive is one way that many communities are trying to meet diversion goals.

\section{Easily Biodegradable}

Food waste is highly biodegradable and has a much higher volatile solids destruction rate $(86-90 \%)$ than bio solids. This means that even though additional material is added to the digesters, the end residual will only increase by a small amount.

\section{PRIMARY AND SECONDARY PROCESS PRIMANRY PROCESS}

i. To collect the organic solid waste and fill the can in layer by layer. Then the waste is filing by waste material is sugar cane waste, goat dunk, vegetable wastes.

ii. Its main think of degradation organic solid waste in waste land and another, this was main function to use the agricultural purpose of manure.

iii. There is three can has been used in this process and they are filling in layer by layer.

iv. This is main process of degradation of organic solid waste for with limited time can do it and my preparation is 4 month of process. v. How many time to taken in the project is maximum 1 to 2 years minimum 3 month but we are taken is 4 month because time duration is less so they are complete the project in limited periods.

vi. This is to collect from manure use of agriculture purpose and to collect leaching of waster and biogas production.

vii. This gas was using to methane gas and biogas uses. The leaching of waster is collected by some positions and limits.

\section{Capacity of the Reactor:}

Reactor $-1=20$ Litters

Reactor $-2=20$ litters

Reactor $-3=20$ litters

\section{REACTOR - I}

Waste collection details:

$\begin{array}{ll}\text { Empty weight of reactor } & =1010 \mathrm{gm} \\ \text { Total waste weight of reactor } & =12600 \mathrm{gm} \\ \text { Total weight of reactor } & =13600 \mathrm{gm}\end{array}$

Reduction of waste weight after 7 days $=300 \mathrm{gm}$

This is full on fully vegetable wastes and damping to filling in weights.

\section{REACTOR - II}

Empty weight of Reactor $\quad=990 \mathrm{gm}$

Total waste weight of reactor $\quad=6000 \mathrm{gm}$

$$
\text { Total weight of reactor } \quad=7000 \mathrm{gm}
$$

Therefore, conducting in two layer of waste filling. They are materials are vegetable waste and sugar cane waste.

$$
\begin{array}{ll}
\text { Vegetable waste weight } & =5200 \mathrm{gm} \\
\text { Sugar can waste weight } & =1600 \mathrm{gm}
\end{array}
$$

Reduction of waste weight after 7 days $=320 \mathrm{gm}$

\section{Fig: 2 REACTORS I \& II}

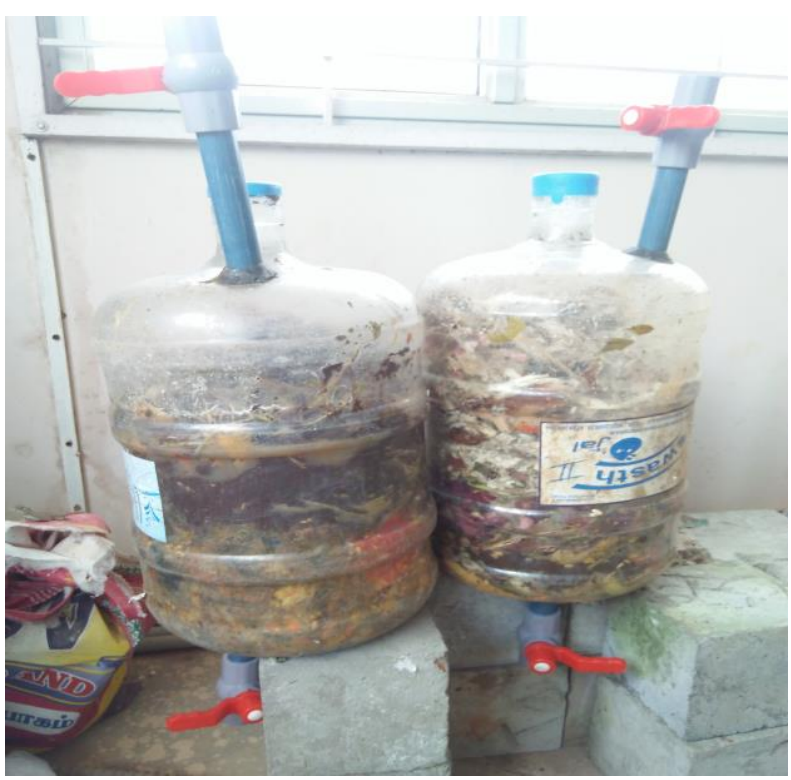

REACTOR-III 


\section{Fig: 3 REACTOR III}

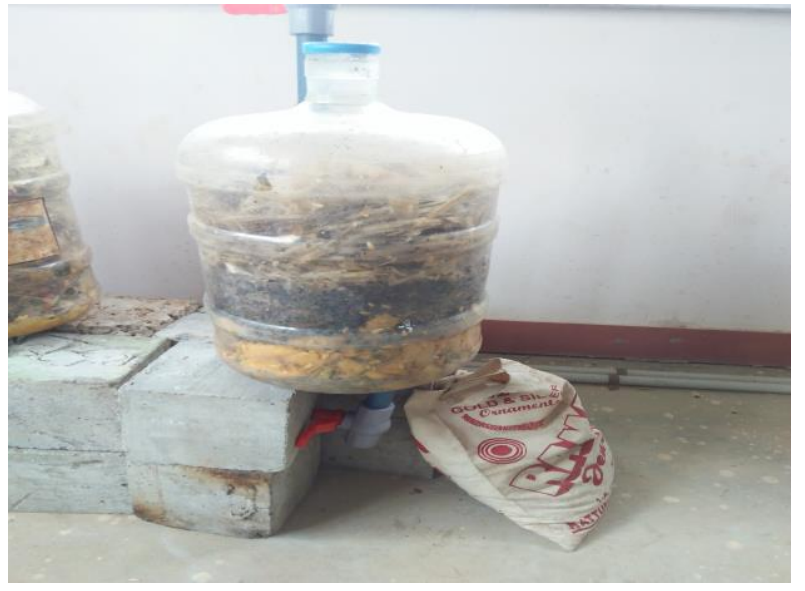

Empty weight of reactor

$=1010 \mathrm{gm}$

Total Weight of waste in reactor

$=6470 \mathrm{gm}$

Total weight of reactor

$=7500 \mathrm{gm}$

Therefore, conducting in three layer of can fillings. They are materials are vegetable waste, goat dunks and sugar cane waste.

Vegetable waste weight

$=3400 \mathrm{gm}$

Goat dunk weight

Sugar cane weight

$=1300 \mathrm{gm}$

$=1800 \mathrm{gm}$

Reduction of waste after 7 days $=200 \mathrm{gm}$.
XVII. SECONDARY PROCESS

\section{SECONDARY PROCESS}

To calculate weight of the reactor after detention time

Fig: 4 REACTOR-I

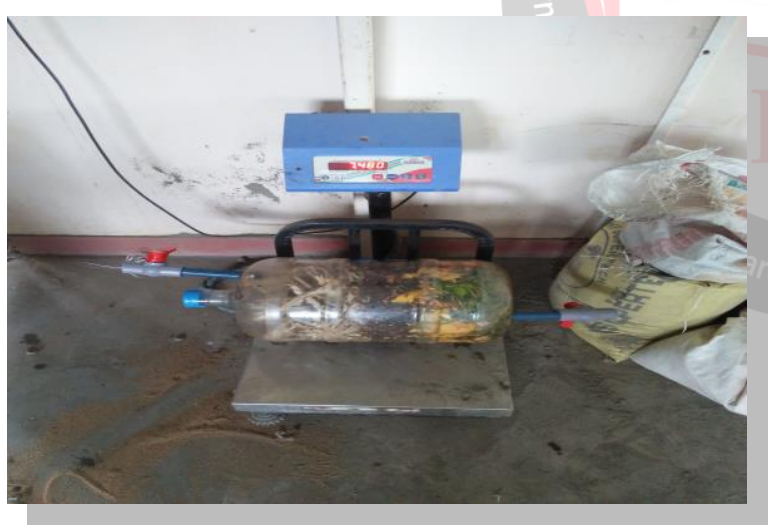

Fig: 5 REACTOR II

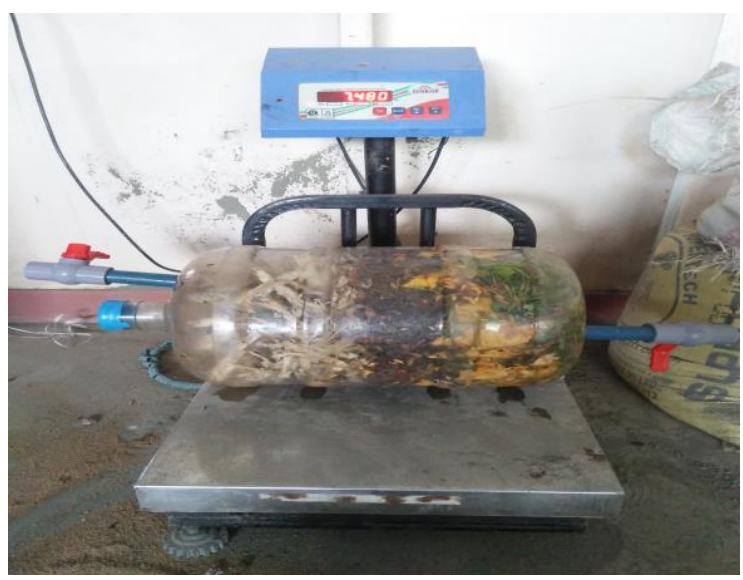

The cans are treatment to 4 month in every week to calculate the readings and reduction of weight has been calculated.

The reduction of waste is the three can is degradation in every week is calculated with in some level of decrease the weight.

\section{CONCLUSION}

It is clear that improper waste management practices have a significant impact on the natural environment and sustainable development in the study area. Thus, awareness about SWM impact on sound environmental development or sustainable development in seemingly low.

Therefore, it is important that the SWM should be developed from the primary level. Waste storage and primary disposal are the dominant means of managing waste. Thus, it has caused significant challenges in the study area.

Therefore, waste separation from the household level, proper storage, more efficient waste collection systems, and sustainable recovery and disposal practices are identified as needed processes in the study area.

Considering the nature and components of waste generated by households and business places, the waste reduction, reuse, recycling and composting processes would be more suitable in managing the challenge. These management options should be integrated in a sustainable framework. Adequate consideration should be given to monitoring processes.

Public education and properly planned waste management programs also need to be introduced into the current waste management system. Especially awareness programmes must be conducted in order to improve the knowledge about the importance of SWM for sound environmental development in the area.

Proper waste disposal is of great importance to both rural and urban areas. Not doing this may bring us to danger in many ways and surely everybody knows this. Time and again, people are always being educated about the importance of waste disposal but then this process should not stop because every now and then, people forget. Some of the kids grow, even if they have learned the proper way of disposing the waste.

We suggest that currently vermicomposting plant is in process in addition to that many flammable materials are to be recycled or by disposed by methods of incineration.

Another suggestion is to make anaerobic digestion plat so that the waste can be effectively utilized and energy is generated in an effective manner.

Finally to form manure use of agriculture purpose and the leaching of water is collected by bottle and biogas was collected. our project was completed and is done by anaerobic digestion of organic solid waste is within 4 month is completed to forms manure and biogas.. 


\section{REFERENCES}

[1] Peter S, Karl W, Jörg C. Conceptual framework for municipal solid waste management in low-income countries. 1st ed. St.Gallen: Swiss Centre for Development Cooperation in Technology and Management; 1996.

[2] Daniel H, Oerinaz BT. WHAT A WASTE - A global review of solid waste management. Washington: World Bank; 2012.

[3] Sustainable waste management, Strengthening waste reduction: Is waste charging an option?. Available online at:

http://www.gov.hk/en/residents/government/publication/consultati on/docs/2012/MSW.pdf. Accessed on 22 Jan 2015.

[4] Ashok VS. Sustainable solid waste management: An integrated approach for Asian countries. Waste Management 2009;29:1438-1448.

[5] Environment Bureau. Hong Kong Blueprint for sustainable use od resources 2013-2022; 2013. Available online at:

http://www.enb.gov.hk/en/files/WastePlan-E.pdf. Accessed on 22 Jan 2015.

[6] Hongtao W, Yongfeng N. Municipal solid waste characteristics and management in China. Air \& Waste Management Assocciation 2001;51:250-263.

[7] Tanmoy K, Bhagat RM, Praduo B. Municipal waste generation, composition, and management: The world scenario. Critical Reviews in Environmental Science and Technology 2012;42:1509-1630.

[8] Somrat K, krongkaew L, Somphot C, Tada U. Testing of RDF gasification from old landfill dump site for electricity generation in a downdraft gasifier. Proceeding of International Conference on Proceeding of International Conference on Applied Enegy (Italy); 16-18 May 2011. Italy.

[9] Junichiro O, Akito M. Tokyo Urban Growth, Unban's form and sustainability. In: Megacities: Urban form, governance, and sustainability, Springer; 2011, p. 15-41.

[10] Waste Management Division, Bureau of Environment, Tokyo Metropolitan Government. Promotion of 3Rs activities inTokyo. Available online at: http://www.asianhumannet.org/db/datas/recycle/activities_in_Tok yo_e_6.pdf. Accessed on 1 Feb 2015.

[11] Ryu C. Potential of Municipal Solid Waste for Renewable Energy Production and Reduction of Greenhouse Gas Emissions in South Korea. Journal of the Air \& Waste Management Association 2010;60:176-183.

[12] Krongkaew L, Somrat K. Green energy recovery of the 500 tons per day waste to energy powerplant for Bangkok Mega City.

Proceeding of International Conference on Proceeding of International Conference/Exhibition on Combustion,Incineration/Pyrolysis, Emission and Climate Change (China); 15-18 October 2014. China.

[13] Waste Management Division, Bureau of Environment, Tokyo Metropolitan Government. Waste Management in Tokyo.Available online at: http://www.asianhumannet.org/db/datas/recycle/activities_in_Tok yo_e_6.pdf. Accessed on 1 Feb 2015.

[14] Yi X, Xuemei B, Zhiyun O, Hua Z, Fangfang X. The composition, trend and impact of urban solid waste in Beijing. Environ Monit Assess 2007;135:21-30.
[15] Environmental Protection Department. Monitoring of solid waste in Hong Kong. Available online at: https://www.waste reduction.gov.hk/sites/default/files/msw2013.pdf. Accessed on 3 Feb 2015.

[16] Yoonjung S. Current MSW management and waste-to-energy status in the Republic of Korea. Dissertation, Columbia University.

[17] Dongqing Z, Tan SK, Richard MG. A comparison of municipal solid waste management in Berlin and Singapore. Waste Management 2010;30;291-933.

[18] Colon, M., Fawcett, B., 2006. Community-based household waste management:lessons learnt from EXNOR's zero waste management scheme in two south Indian cities. Journal ofHabitat International 30 (4), 916-931.

[19] Gupta, P.K., Jha, A.K., Koul, S., Sharma, P.Pradhan, V., Gupta, V.,Sharma, C., Singh, N., 2007. Methane and Nitrous Oxide Emission from Bovine Manure Management Practices in India. Journal of Environmental Pollution 146 (1), 219-224.

[20] Sannigrahi, A.K., Chakrabortty, S., 2002. Beneficial management of organic waste by vermicomposting. Indian Journal of Environmental Protection 22 (4), 405-408.

[21] Raje, D.V., Wakhare, P.D., Despande, A.W., Bhide, A.D., 2001. An approach to assess level of satisfaction of the residents in relation to SWM system. Journal of Waste Management and Research 19, 12-19.

[22] Sudhire, V., Muraleedharan, V.R., Srinivasan, G., 1996. Integrated solid waste management in urban India: a critical operational research framework. Journal of Socio-economic Planning Science 30 (3), 163-181.

[23] Ministry of Environment and Forests (MoEF), 2000. The Gazette of India. Municipal Solid Waste (Management and Handling) Rules, New Delhi, India.

[24] Mor, S., Ravindra, K., Visscher, A.D., Dahiya, R.P., Chandra, A., 2006.Municipal solid waste characterization and its assessment for potential methane generation: a case study. Journal of Science of the TotalEnvironment 371 (1), 1-10.

[25] Jalan, R.K., Srivastava, V.K., 1995. Incineration, land pollution control alternative - design considerations and its relevance for India. Indian Journal of Environmental Protection 15 (12), 909-913.

[26] Kansal, A., 2002. Solid waste management strategies for India. Indian Journal of Environmental Protection 22 (4), 444448.

[27] Malviya, R., Chaudhary, R., Buddhi, D., 2002. Study on solid waste assessment and management - Indore city. Indian Journal of Environmental Protection 22 (8), 841-846.

[28] Maudgal, S., 1995. Waste management in India. Journal of Indian Association for Environmental Management 22 (3), 203 208.

[29] Rathi, S., 2006. Alternative approaches for better municipal solid waste management in Mumbai, India. Journal of Waste Management 26 (10), 1192-1200.

[30] Pappu, A., Saxena, M., Asokar, S.R., 2007. Solid Waste Generation in India and Their Recycling Potential in Building Materials. Journal of Building and Environment 42 (6), 2311 2324 